\title{
THE EFFECT OF ACETYLCHOLINE CONCENTRATION ON MEMBRANE POTENTIAL, REDOX STATE AND SECRETION OF THE PANCREATIC ACINAR CELL
}

\author{
TOMIO KANNO* and YOSHIAKI HABARA
}

Department of Physiology, Faculty of Veterinary Medicine, Hokkaido University, Sapporo 060, Japan

\begin{abstract}
Continuous stimulation of the isolated perfused rat pancreas with acetylcholine $(\mathrm{ACh})$ at a low concentration $\left(5 \times 10^{-8} \mathrm{M}\right)$ induced flat increases in secretory responses, which were decreased to values of about 30 per cent of control obtained in the standard medium when calcium was omitted from the perfusing and bathing solution. The secretory responses were associated with little or no change in the membrane potential and the redox state of the acinar cells.

Continuous stimulation with $\mathrm{ACh}$ at a moderate concentration $\left(3 \times 10^{-7} \mathrm{M}\right)$ induced secretory responses which consisted of the following three phases; initial rise, second plateau and the final decline. When calcium was removed from the perfusing and bathing solution, the initial phase was decreased to about a half of the control obtained in the standard medium, and the second and the final phase were strongly inhibited. Continuous stimulation with $3 \times 10^{-7} \mathrm{M}$ ACh caused only a transient small depolarization of the acinar cell, and a gradual reduction in the redox state.

Continuous stimulation with $\mathrm{ACh}$ at a higher concentration $\left(10^{-6} \mathrm{M}\right)$ induced a rather small flat increase in amylase output, which was further enhanced when calcium was removed from the perfusing and bathing solution. Continuous stimulation with $10^{-6} \mathrm{M}$ ACh caused a transient oxidation followed by a gradual reduction in the redox state.
\end{abstract}

KEY WORDS acetylcholine / membrane potential / redox state / secretion / pancreatic acinar cell

Cholecystokinin-pancreozymin (CCK-PZ) and acetylcholine $(\mathrm{ACh})$ are the physiological secretagogues to which the pancreatic acinar cells respond by releasing their contents of zymogen granules. It is commonly believed that the effect of these secretagogues is exerted by increasing the cytoplasmic concentration of free, diffusible $\mathrm{Ca}$, although no direct measurement of intracellular free $\mathrm{Ca}$ concentration, $[\mathrm{Ca}] \mathrm{i}$, has yet been made in pancreatic acinar cells (2). Two views have been proposed on the nature

*To whom reprint requests should be made of the process responsible for the secretagogueinduced rise in $[\mathrm{Ca}]_{i}$. One view is that the rise may be produced by an increase in $\mathrm{Ca}$ entry into the pancreatic acinar cell, and the second view is that the rise may be due to a release of $\mathrm{Ca}$ from an intracellular Ca store $(2,5)$. A previous study in our laboratory provided evidence that the amylase output induced by $5 \mathrm{mU} / \mathrm{ml}$ CCK-PZ was inhibited by the addition of $\mathrm{Mn}$, an inhibitor of the $\mathrm{Ca}$ influx (10). The present experiments showed that the secretory response induced by $\mathrm{ACh}$ at a low concentration (5 $\times 10^{-8} \mathrm{M}$ ) was strongly reduced in a Ca-defi- 
cient environment, while the response induced by $\mathrm{ACh}$ at a higher concentration $\left(10^{-6} \mathrm{M}\right)$ was not inhibited but rather enhanced by the Ca removal.

Continuous stimulation with $\mathrm{ACh}$ at the low concentration induced neither depolarization nor an increase in fluorescence of the pyridine nucleotides, whereas continuous stimulation with $\mathrm{ACh}$ at the higher concentration caused transient depolarization and gradual increase in fluorescence of the pyridine nucleotides. These observations show that the cellular processes in stimulus-secretion coupling induced by $\mathrm{ACh}$ at the low concentration may differ from those induced by $\mathrm{ACh}$ at higher concentrations.

\section{METHODS}

\section{Isolation and Perfusion of the Pancreas}

Male rats of Wistar strain weighing about $200 \mathrm{~g}$ were fasted but allowed water for $24 \mathrm{hr}$ before the experiments. The isolated and perfused pancreas was prepared as reported previously (13). Briefly, under ether anesthesia, the vascular system was cannulated and perfused through the superior mesenteric and coeliac arteries, with the portal vein as outlet. The rate of vascular flow was kept constant at $1.3 \mathrm{ml}$ / min by a roller pump in the experiments demonstrating the effects of $\mathrm{ACh}$ on the secretory response and membrane potential, and $2 \mathrm{ml} /$ min in the experiments demonstrating the effects of $\mathrm{ACh}$ on the secretory response and the redox state. The hepatic end of the common duct was ligated and the pancreatic juice was collected from the duodenal end of the duct following cannulation with a stainless-steel tube (the draining preparation). The flushing preparation (13) was used in the experiments recording simultaneously the secretory response and the membrane potential or the redox state. The blood supplying the stomach, liver and spleen was stopped by tying the arteries. The mesentery with its embedded whole pancreas and the attached duodenum was then placed in a Lucite chamber containing $20 \mathrm{ml}$ of a modified Krebs-Henseleit solution, maintained at $37^{\circ} \mathrm{C}$.

\section{Hormones, Drugs and Solution}

The composition of the standard Krebs-Henseleit solution used for perfusing and bathing the preparation was as follows (final concentrations, $\mathrm{mM}$ ): $\mathrm{NaCl}, 131 ; \mathrm{KCl}, 5.6 ; \mathrm{CaCl}_{2}, 1.0$; $\mathrm{NaHCO}_{3}, 25 ; \mathrm{MgCl}_{2}, 1.0 ; \mathrm{NaH}_{2} \mathrm{PO}_{4}, 1.0 ;$ glucose, 5.0. In the low $\mathrm{Ca}$ and the $\mathrm{Ca}$-deficient solutions, $\mathrm{CaCl}_{2}$ was replaced with isotonic amounts of NaCl. Dextran T-70 (Pharmacia, Uppsala) was added to the perfusing solution at a final concentration of $5 \%(\mathrm{w} / \mathrm{v})$. The solution was equilibrated with $5 \% \mathrm{CO}_{2}$ in $\mathrm{O}_{2}$ and had a $\mathrm{pH}$ of about 7.4. Highly purified natural CCK-PZ (3500 U/ml, GIH Research Unit, Karolinska Institute, Stockholm) was added into the perfusing solution. The concentration of CCK-PZ was expressed in Ivy dog units (7). $\mathrm{ACh}$ (Sigma, St. Louis) was also added into the perfusing solution.

\section{Estimation of Digestive Enzyme and Flow of Pancreatic Juice}

The estimation of the flow rate of pancreatic juice was made as follows: a calibrated tube made of silicon-rubber (about $0.5 \mathrm{~mm}$ in outer diameter) was attached to the free end of the pancreatic duct cannula. At specified intervals the tube was replaced and the rate of pancreatic juice flow down the tube was measured. The collected juice sample was then diluted with 160 $\mathrm{mM} \mathrm{NaCl}$ solution containing phosphate-buffer (pH 7.1). Amylase in appropriately diluted samples was assayed by the method of Bernfeld (1) as modified previously (9). One unit of amylase activity is defined as the amount of enzyme which produced $1 \mathrm{mg}$ maltose during a $5 \mathrm{~min}$ incubation at $37^{\circ} \mathrm{C}$.

\section{Recording of Membrane Potentiaı}

Intracellular recordings were made from the pancreatic acinar cells by manually advancing $\mathrm{KCl}$-filled microelectrodes under direct visual control with the aid of a micromanipulator driven by oil pressure (Narishige, MO $102 \mathrm{R}$, Tokyo). Resting potentials were observed on the screen of a cathode ray oscilloscope (Nihon Koden, ATAC-250, Tokyo) and simultaneously recorded on a direct visual oscillograph (Yokogawa, type 2915, Tokyo) with a frequency response of $5 \mathrm{kHz}$. Current pulses of $50 \mathrm{msec}$ duration were passed through the recording electrode in order to polarize the cell membrane. A full description of the procedure has been given in previous papers $(6,8)$.

\section{Recording of Redox State}

Redox state of the isolated and perfused rat pancreas was recorded with a redoximeter (Tateishi Institute of Life Sciences, type HEF-4, Kyoto). The mechanical and electrical details of 
A

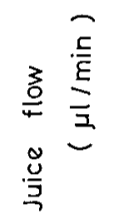

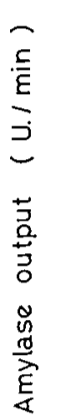

$\left.\begin{array}{c}1.0 \\ 0.5 \\ 0\end{array}\right]$

B
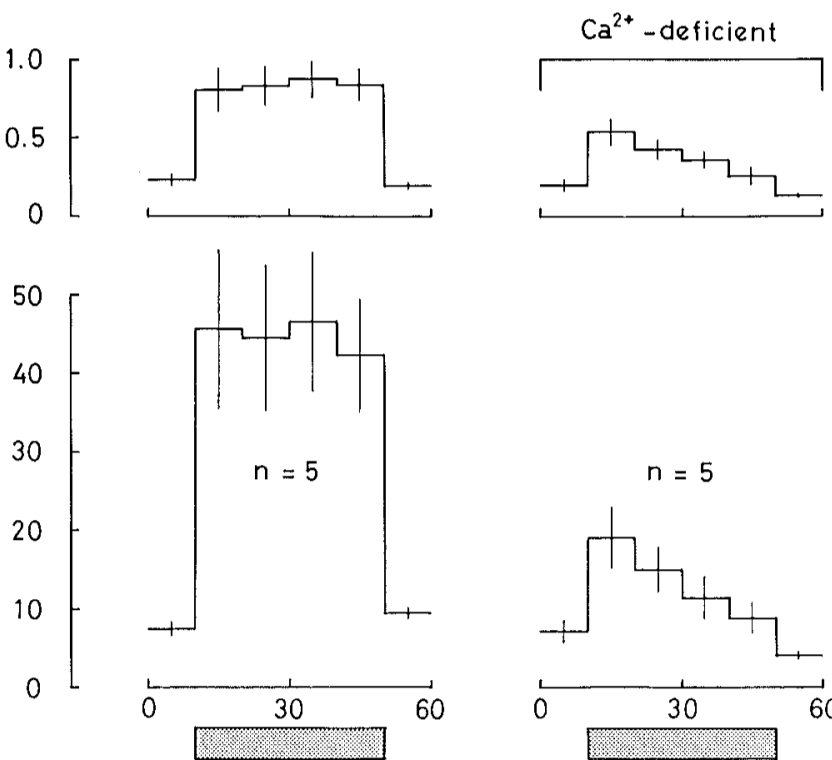

$5 \times 10^{-8} \mathrm{M}-\mathrm{ACh}$

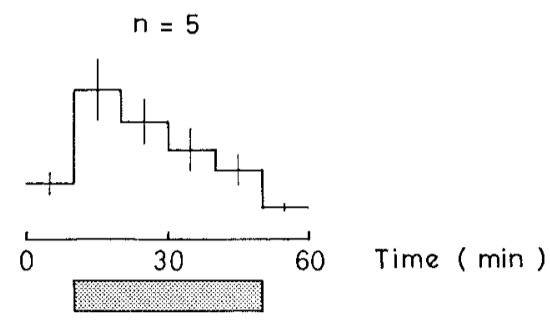

Fig. 1 Time course of changes in pancreatic juice flow and amylase output during continuous perfusion of the isolated pancreas with $5 \times 10^{-8} \mathrm{M} \mathrm{ACh}$ in the standard medium (A). In Fig. 1B, the perfusion medium was changed from the standard medium to a Cadeficient medium in the course of continuous stimulation. Each value represents the mean of several experiments as indicated. The stippled horizontal bar indicates the period of $\mathrm{ACh}$ perfusion.

this instrument were described by Kobayashi (15). Briefly, the instrument is a modification of the microfluorometer introduced by Chance, Cohen, Jobsis and Schoener (4) that records blue fluorescence emitted from the microscopic field of tissues upon the $366 \mathrm{~nm}$ excitation-light. The fluorescence intensity is a function of the amount of reduced form of the pyridine nucleotides (nicotinamide adenine dinucleotide, $\mathrm{NADH}$, and nicotinamide adenine dinucleotide phosphate, NADPH), and a direct and continuous measurement of the relative value of the intracellular redox state can thus be attained.

\section{Statistics}

Results are expressed as the mean $\pm \mathrm{S}$. E. of several experiments $(n)$, and are analyzed by Student's $t$-test.

\section{RESULTS}

\section{Influence of Ca Removal on Secretory}

\section{Responses Induced by ACh at Different Concentrations}

Continuous stimulation with $\mathrm{ACh}$ at a low concentration $\left(5 \times 10^{-8} \mathrm{M}\right)$ induced flat increases in amylase output and pancreatic juice flow (Fig. 1A). The total amylase output in the initial $40 \mathrm{~min}$ of continuous stimulation in the standard medium was $1633.0 \pm 427.5 \mathrm{U}$. The secretory responses were strongly reduced when $\mathrm{Ca}$ was removed from the perfusing and bathing solution (Fig. 1B). The total amount of ACh-induced amylase output into the common duct collected in the $\mathrm{Ca}$-deficient environments was $555.0 \pm 112.0 \mathrm{U}$ per $40 \mathrm{~min}$. Analysis of these two results showed that the diminution of ACh-induced amylase output in Ca-deficient environments was significant $(P<0.05)$. Residual $\mathrm{Ca}$ released from the isolated pancreas into the vascular perfusate was measured with an atomic absorption spectrophotometer (HitachiPerkin-Elmer, model 303). About $0.02 \mathrm{mM} \mathrm{Ca}$ still remained in the perfusate even after $40 \mathrm{~min}$ of perfusion with the Ca-deficient solution. The 
secretory responses that remained in the $\mathrm{Ca}$ deficient environment could thus be due to the presence of a small amount of $\mathrm{Ca}$ in the extra. cellular environment surrounding the acinar parenchyma.

Continuous stimulation with $\mathrm{ACh}$ at a moderate concentration $\left(3 \times 10^{-7} \mathrm{M}\right)$ induced secretory responses which consisted of the following three phases; initial rising, second plateau and the final decline (Fig. 2A). The total amylase output in the initial $40 \mathrm{~min}$ of continuous stimulation in the standard medium was 3328.0 $\pm 535.2 \mathrm{U}$. When $\mathrm{Ca}$ was removed from the perfusing and bathing solution, the initial phase was decreased to about a half of the control obtained in the standard medium, and the second and the final phase were strongly inhibited. The total amount of ACh-induced amylase output into the common duct collected in the $\mathrm{Ca}$-deficient environments was $1199.7 \pm 235.0 \mathrm{U}$ per $40 \mathrm{~min}$. Analysis of these two results showed that the diminution of $\mathrm{ACh}$-induced amylase output in $\mathrm{Ca}$-deficient environments was significant $(P<0.01)$.

Continuous stimulation with $\mathrm{ACh}$ at a higher concentration $\left(10^{-6} \mathrm{M}\right)$ induced a rather small

A
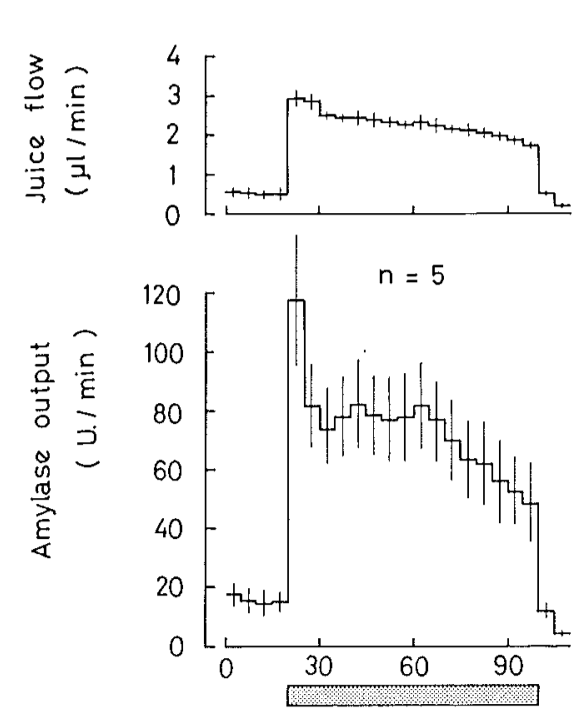

$3 \times 10^{-7} \mathrm{M}-\mathrm{ACh}$ flat increase in amylase output into the common duct associated with a gradual increase in output into the portal vein (Fig. 3A). The total amount of ACh-induced amylase output into the common duct in the initial 40 min of continuous stimulation in the standard medium was $888.7 \pm 127.5$ U. A previous study (20) showed that continuous stimulation with pancreozymin at a higher concentration induced rather a small amylase output into the common duct and a large output into the portal vein. When $\mathrm{Ca}$ was removed from the perfusing and bathing solution, the initial phase of AChinduced amylase output was rather enhanced (Fig. 3B). The total amount of ACh-induced amylase output into the common duct collected in the Ca-deficient environment was 797.1士 $164.7 \mathrm{U}$ per $40 \mathrm{~min}$. Analysis of these two results showed that the diminution of AChinduced amylase output in Ca-deficient environments was not significant $(P>0.6)$.

\section{Membrane Potential and Amylase Output}

Fig. 4 shows a typical recording of intracellular membrane potential and effective membrane

B
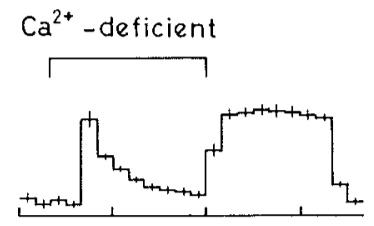

$n=5$

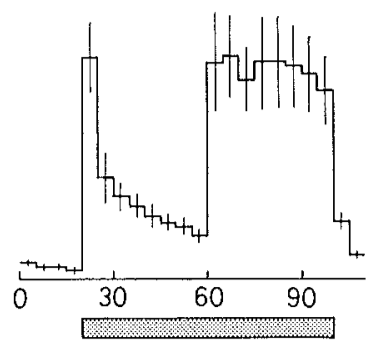

Time ( $\min )$

Fig. 2 Time course of changes in pancreatic juice flow and amylase output during continuous perfusion of the isolated pancreas with $3 \times 10^{-7} \mathrm{M} \mathrm{ACh}$ in the standard medium (A). The perfusion medium was changed from the standard medium to a Ca-deficient medium in the course of continuous stimulation (B). Each value represents the mean of several experiments as indicated. The stippled horizontal bar indicates the period of $\mathrm{ACh}$ perfusion. 
A
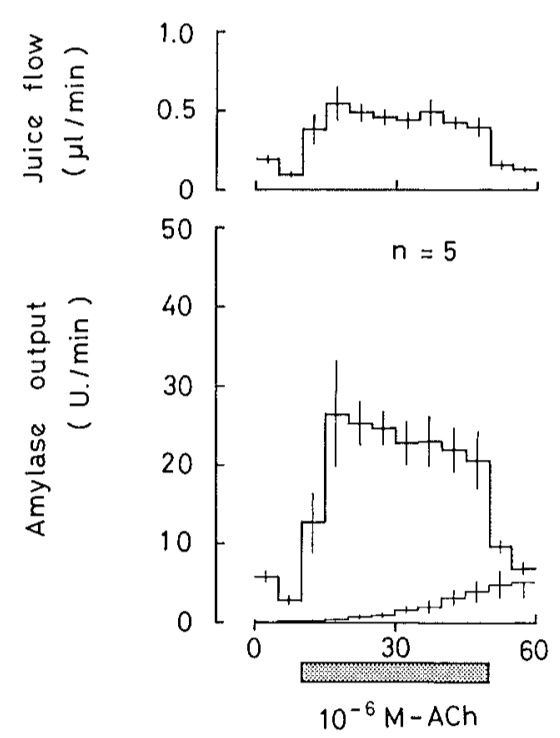

$8 \mathrm{Ca}^{2+}$-deficient
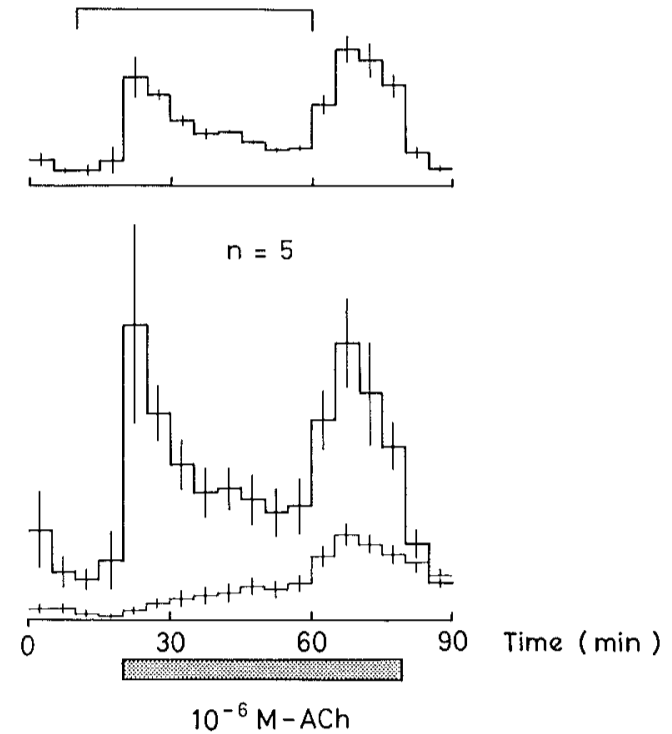

Fig. 3 Time course of changes in pancreatic juice flow and amylase output during continuous perfusion of the isolated pancreas with $10^{-6} \mathrm{M}$ ACh in the standard medium (A). The perfusion medium was changed from the standard medium to a $\mathrm{Ca}$-deficient medium in the course of continuous stimulation (B). Each value represents the mean of several experiments as indicated. The thin stepped line represents output into the portal vein. The stippled horizontal bar indicates the period of ACh perfusion.

resistance from an acinar cell of the perfused pancreas. Perfusion with the standard solution containing $5 \times 10^{-8} \mathrm{M}$ ACh resulted in a minute depolarization followed by gradual recovery towards the resting level. The depolarization was associated with a burst of miniature depolarizations and these changes coincided with a definite increase in amylase output into the common duct (Fig. 4).

One minute stimulation with $10^{-5} \mathrm{M}$ ACh was enough to cause a slow and large depolarization of an acinar cell which coincided with a small increase in amylase output into the common duct (Fig. 5). The regain of output immediately after the initial small increase induced by $10^{-5} \mathrm{M}$ ACh may be due to a response for diluted $\mathrm{ACh}$, since continuous stimulation with $10^{-5} \mathrm{M}$ ACh caused only a small transient increase in amylase output into the common duct (Y. Habara, unpublished data) (Fig. 5). ACh, $10^{-7} \mathrm{M}$, evoked a small transient depolarization of the same acinar cell, and a definite increase in amylase output (Fig. 5).

\section{Redox State and Amylase Output}

A clue to the mode of action of mitochondria in an intact cell has been provided by studies made with the measurement of the NAD $(\mathrm{P}) \mathrm{H}$ fluorescence (4). Fig. 6 shows a typical recording of the $\mathrm{NAD}(\mathrm{P}) \mathrm{H}$-fluorescence from the isolated and perfused pancreas. Perfusion with the standard solution containing $5 \times 10^{-8} \mathrm{M}$ ACh produced almost no change in the fluores cence except a small transient deflection immediately after initiation and termination of the continuous stimulation, and this change coincided with a transient rise in amylase output followed by a prolonged output into the common duct. Continuous stimulation with $3 \times$ $10^{-7} \mathrm{M} \mathrm{ACh}$ in the standard medium induced an increase in NAD(P)H-fluorescence (reduction) towards a maximum of $20 \%$ of the resting level (Fig. 7). This change coincided with the initial rise in amylase output followed by gradually declining phase of output into the common duct (Fig. 7).

Continuous stimulation with $10^{-6} \mathrm{M} \mathrm{ACh}$ in the standard medium induced a transient decrease followed by a gradual increase in NAD (P)H-fluorescence towards a maximum of $20 \%$ of the resting level. This change coincided with a slight increase in amylase output into the common duct (Fig. 8). 

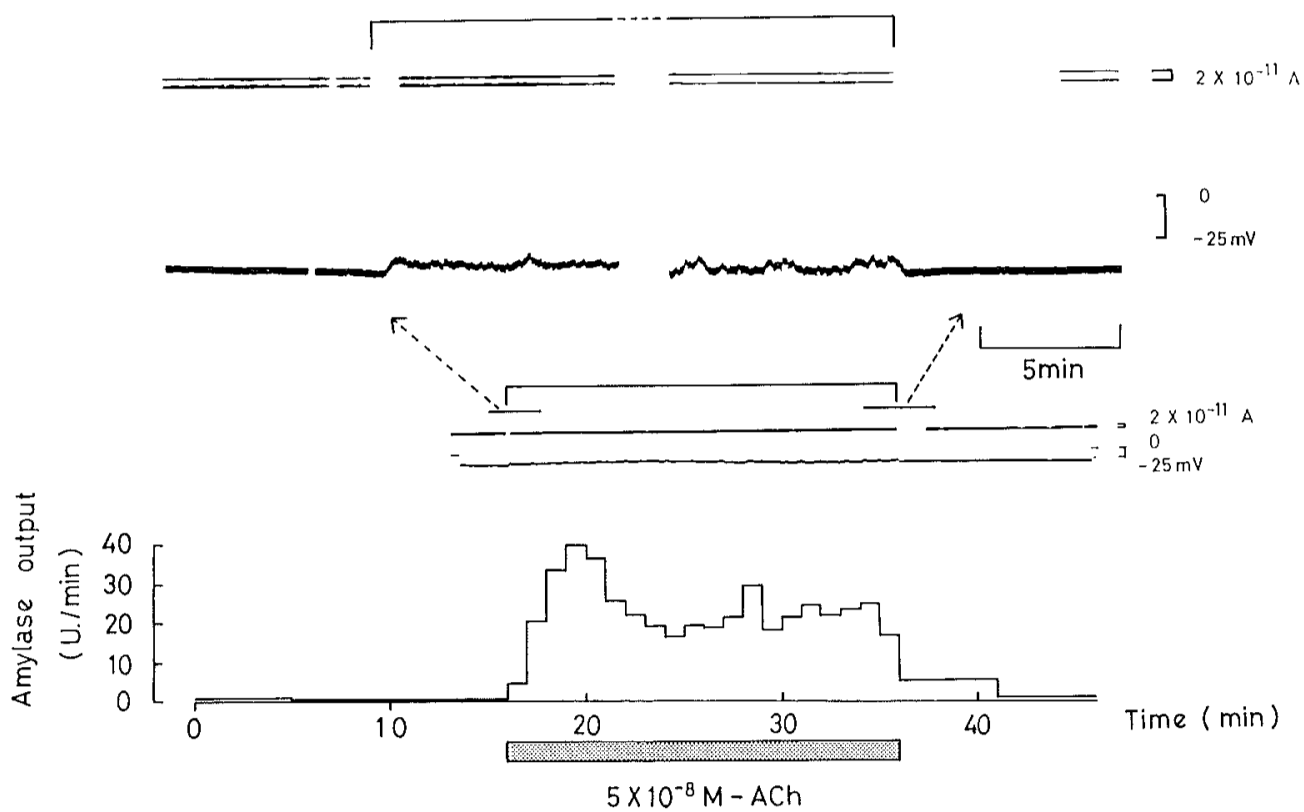

Fig. 4 An example of a recording of membrane potential with superimposed displacements resulting from the passage of current pulses $(50 \mathrm{msec}$ duration) through the recording electrode. The bar above the current recording indicates the period of perfusion with the standard solution containing $5 \times 10^{-8} \mathrm{M} \mathrm{ACh}$. The top records are the parts of continuous recording (shown by the dashed arrows) at high magnitude in the interest of distinguishing the burst of miniature depolarizations during the continuous stimulation. The time course of amylase output of this flushing preparation is shown by the stepped line. The stippled horizontal bar indicates the period during which $\mathrm{ACh}$ was present.

\section{DISCUSSION}

\section{$[\mathrm{Ca}]_{o}$ on the Secretory Response}

The present experiments provide evidence that $\mathrm{ACh}$ requires external $\mathrm{Ca}$ in the perfusing solution in order to induce amylase output in the isolated and perfused rat pancreas. The requirement of external $\mathrm{Ca}$ was clearly demonstrated when the pancreas was stimulated with $5 \times 10^{-8}$ $\mathrm{MACh}$. This is in agreement with the result obtained in the secretory response induced by $5 \mathrm{mU} / \mathrm{ml}$ CCK-PZ $(10,12,14)$.

\section{Membrane Potential and Secretory Responses}

It has been suggested that there are two components in the effect of CCK-PZ on the membrane potential of the acinar cells: transient depolarization which coincides with an increase in $\mathrm{Na}$ permeability in the initial phase, and continuous hyperpolarization due to an electro. genic $\mathrm{Na}$ pump which conceals the transient depolarizing phase when the pump is dominant (9). This view was supported by the fact that
CCK-PZ at $5 \mathrm{mU} / \mathrm{ml}$ hyperpolarized the pancreatic acinar cell, and the hyperpolarization was inhibited in the environments that excluded the contribution of the electrogenic Na pump to the membrane potentials of nerve and muscle cells (9). It seems possible that the initial phase corresponds to the inward movement of the complex composed of a carrier molecule bearing $\mathrm{Ca}$ and $\mathrm{Na}$ ions, and the latter hyperpolarizing phase is due to the activity of the $\mathrm{Na}$ pump $(11,12)$. A stable counterbalance between the hyperpolarizing and depolarizing effect may be an explanation for the present result that $5 \times$ $10^{-8} \mathrm{M}$ ACh caused almost no change in membrane potential coinciding with a sustained amylase output. The counterbalance, however, seems to reflect on the burst of miniature depolarizations recorded during the continuous stimulation with $5 \times 10^{-8} \mathrm{M}$ ACh.

\section{Redox State and Secretory Response}

Mitochondria of animal tissues are very active in respiration-coupled inward transport of cytoplasmic free $\mathrm{Ca}$ (for reference, see 16), which 


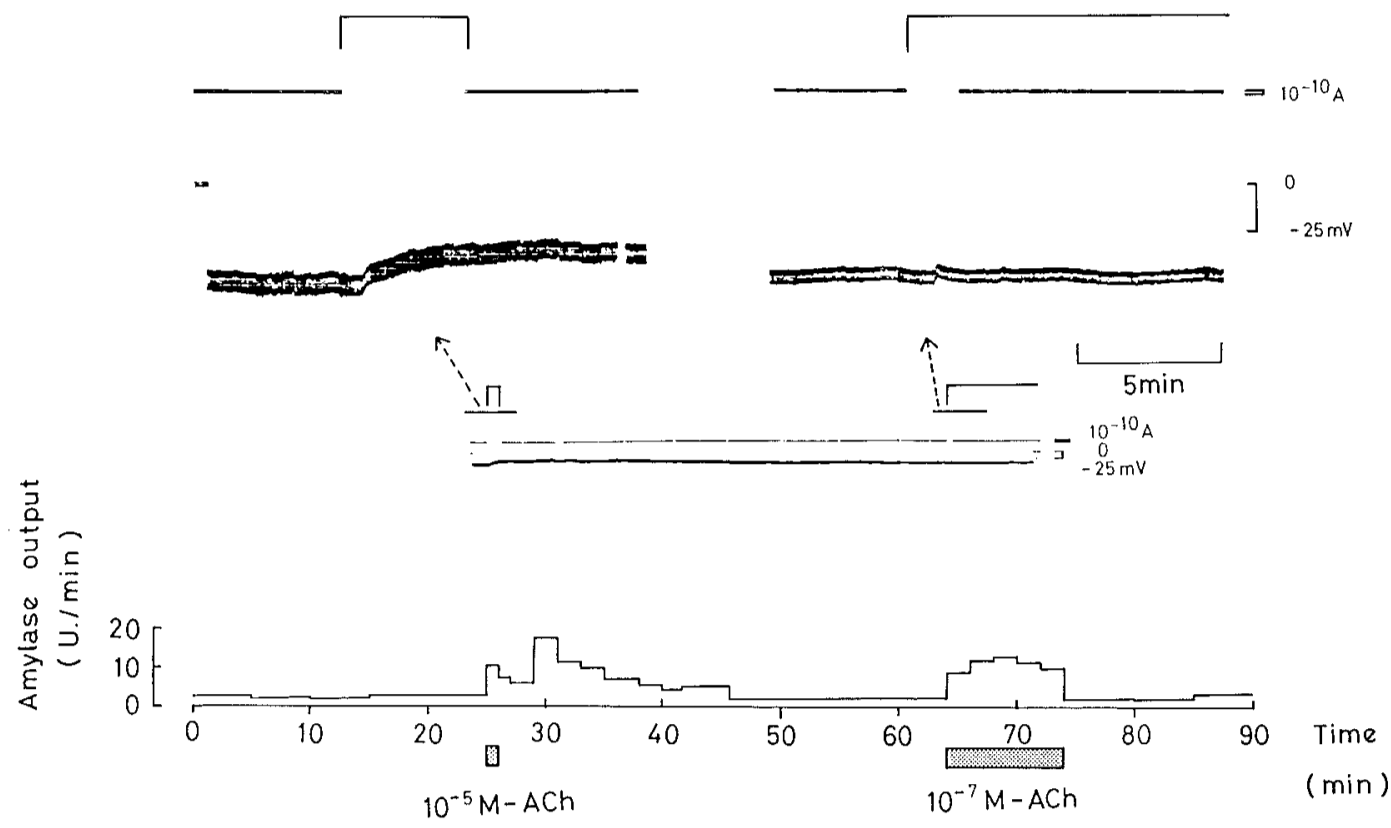

Fig. 5 An example of a recording of membrane potential with superimposed displacements resulting from the passage of current pulses $(50 \mathrm{msec}$ duration) through the recording electrode. The bars above the current recording indicates the period of perfusion with the solution containing $10^{-5} \mathrm{M} \mathrm{ACh}$ and $10^{-7} \mathrm{M} \mathrm{ACh}$, respectively. The top records are the parts of continuous recording (shown by the dashed arrows) at high magnitude in the interest of distinguishing the change in membrane potential. The time course of amylase output of this preparation is shown by the stepped line. The stippled horizontal bar indicates the period during which $\mathrm{ACh}$ was present.
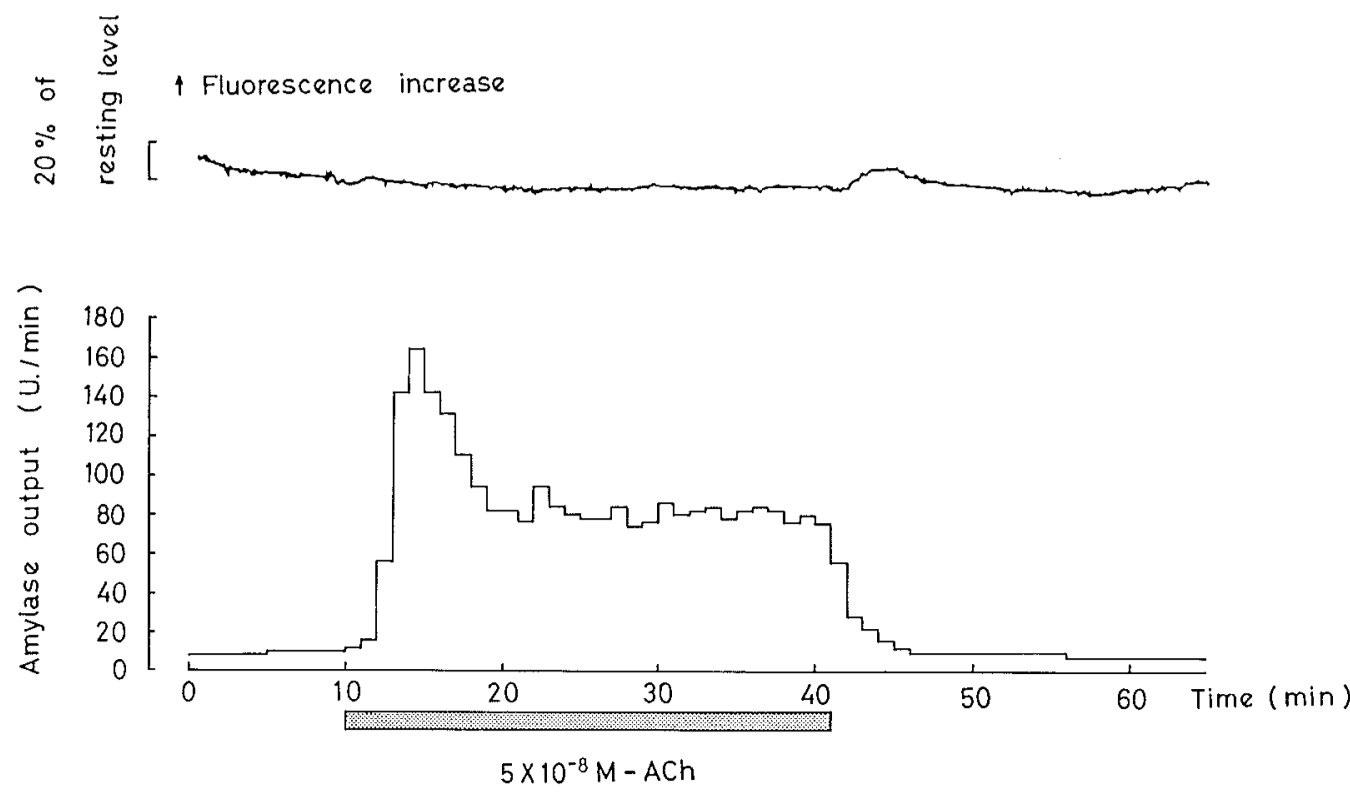

Fig. 6 An example of a long recording of $\mathrm{NAD}(\mathrm{P}) \mathrm{H}$-fluorescence combined with a simultaneous measurement of amylase output. The stippled horizontal bar indicates the period during which $5 \times 10^{-8}$ M ACh was present. Note that, in this experiment, the vascular flow was $2 \mathrm{ml} / \mathrm{min}$, which was about 1. 5 -fold as much as the rate used in the preceding experiments. 
may determine the rate of extrusion of zymogen granules. It is also known that the inward transport of cytoplasmic $\mathrm{Ca}$ coincides with inhibition of ATP reproduction in the mitochondria (16). The activity of mitochondria may reflect on the oxidation-reduction state of the pyridine nu- cleotides (redox state). Simultaneous recordings of the redox state and amylase output showed that continuous stimulation with $5 \times$ $10^{-8} \mathrm{M} \mathrm{ACh}$ induces a gradual and slight increase in $\mathrm{NAD}(\mathrm{P}) \mathrm{H}$-fluorescence and a definite and continuous increase in amylase output. An
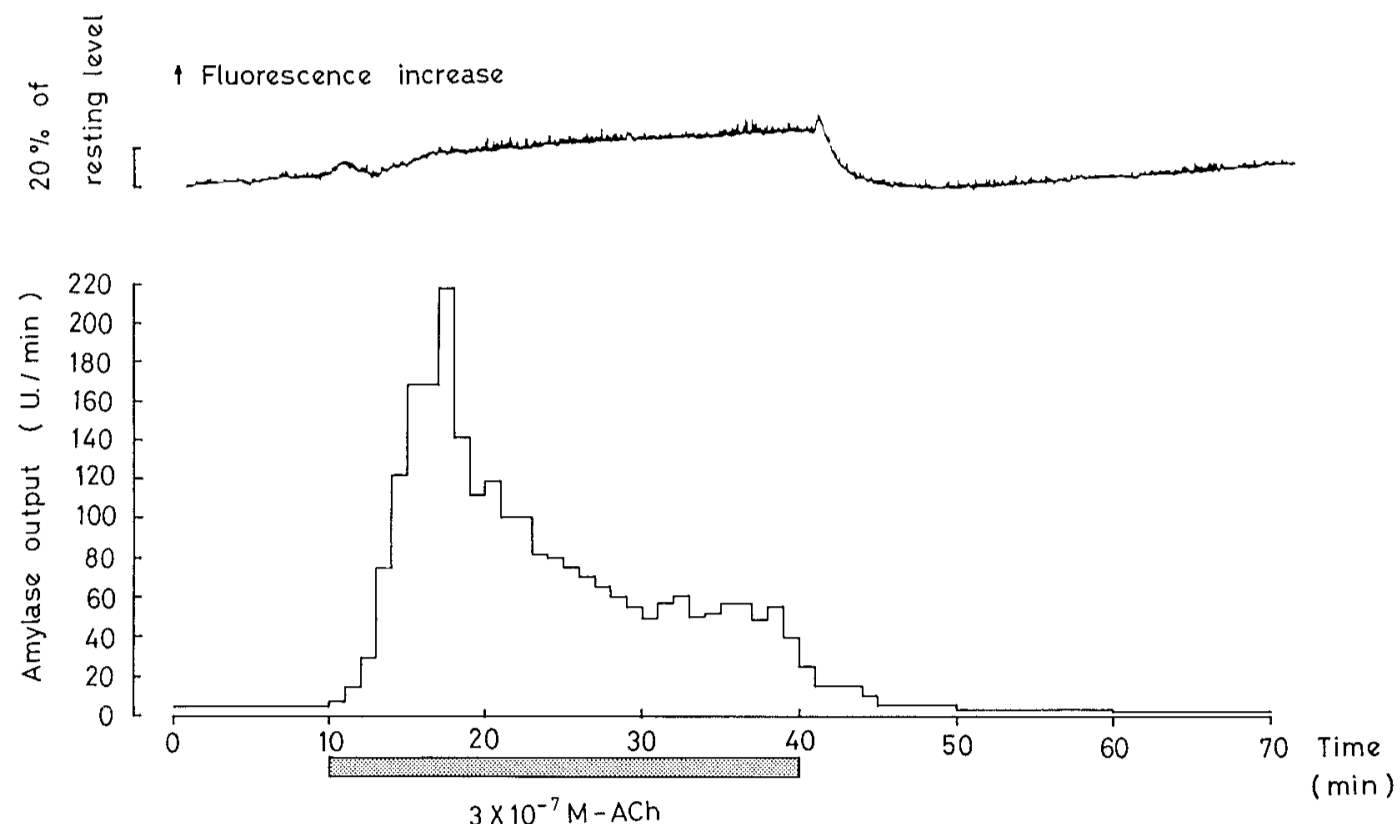

Fig. 7 An example of a long recording of $\mathrm{NAD}(\mathrm{P}) \mathrm{H}$-fiuorescence combined with a simultaneous measurement of amylase output. $3 \times 10^{\rightarrow 7} \mathrm{M} \mathrm{ACh}$ was present. Note that the vascular flow was $2 \mathrm{ml} / \mathrm{min}$ in this experiment.
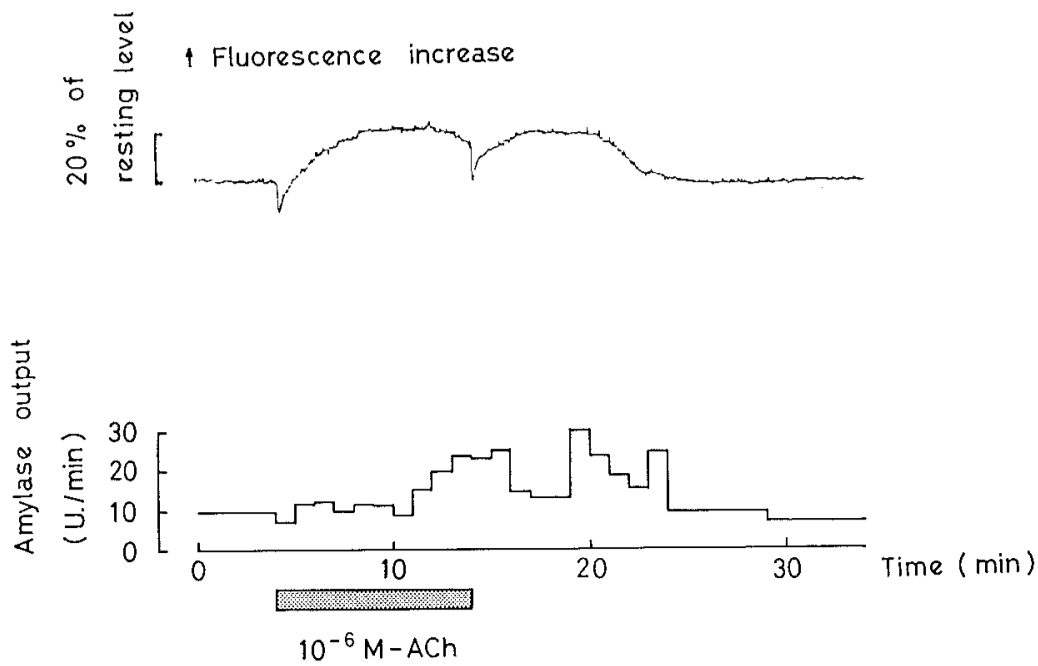

Fig. 8 An example of a long recording of NAD(P)H-fluorescence combined with a simultaneous measurement of amylase output. The stippled horizontal bar indicates the period during which $10^{-6} \mathrm{M}$ ACh was present. Note that the vascular flow was $2 \mathrm{ml} / \mathrm{min}$ in this experiment. 
interpretation of these results may be that the secretory response induced by $5 \times 10^{-8} \mathrm{M}$ ACh coincides with a counterbalance between the activity of mitochondria reproducing ATP and the inverse activity of transporting cytoplasmic $\mathrm{Ca}$.

\section{Response Induced by ACh at a Higher Concentration}

The responses induced by $3 \times 10^{-7} \mathrm{M}$ ACh were different from those induced by $5 \times 10^{-8} \mathrm{M}$ ACh. In the standard medium, $3 \times 10^{-7} \mathrm{M} \mathrm{ACh}$ induced (a) a rapid increase in amylase output followed by a rapid declining phase, (b) a small transient depolarization, and (c) a gradual increase in $\mathrm{NAD}(\mathbf{P}) \mathrm{H}$-fluorescence. The present result that $3 \times 10^{-7} \mathrm{M}$ ACh caused no change in the membrane potential is in agreement with the result shown by Petersen and Matthews (18). In the $\mathrm{Ca}$-deficient medium, $\mathrm{ACh}$ at the same concentration $\left(3 \times 10^{-7} \mathrm{M}\right)$, induced a rapid increase in amylase output followed by a further acceleration of the declining phase.

The response induced by $10^{-6} \mathrm{M} \mathrm{ACh}$ was a small increase in amylase output which was not diminished in the Ca-deficient medium, and which was followed by a gradual increase in amylase output into the portal vein. Continu. ous stimulation with $10^{-6} \mathrm{M}$ ACh caused a transient decrease in $\mathrm{NAD}(\mathbf{P}) \mathrm{H}$-fluorescence (oxidation) followed by a gradual increase in the fluorescence. If these changes in fluorescence may, at least in part, be a reflection of the activity of mitochondrial pyridine nucleotides in the pancreatic acinar cells, the following mechanism demonstrated in isolated mitochondria (16) may also be applied to the acinar cells: a relatively reduced state of the mitochondrial pyridine nucleotides promotes uptake and retention of $\mathrm{Ca}$ and a relatively oxidized state promotes $\mathrm{Ca}$ release from the mitochondria. The increase in $[\mathrm{Ca}]_{\mathrm{i}}$ may in turn cause an increase in the rate of exocytosis of the zymogen granules. The responses induced by $10^{-5} \mathrm{M}$ ACh were a small increase in amylase output which coincided with a definite transient depolarization.

These results lead us to conclude that the influx of external $\mathrm{Ca}$ is decreased and the release of $\mathrm{Ca}$ from an intracellular $\mathrm{Ca}$ store is increased when the pancreas is stimulated with ACh at the higher concentration. The present conclusion is consistent with the results reported in previous papers as follows. Case and Clausen (3) showed that amylase released by $10^{-5} \mathrm{M}$
ACh or $50 \mathrm{mU} / \mathrm{ml} \mathrm{CCK-PZ} \mathrm{was} \mathrm{not} \mathrm{affected} \mathrm{by}$ a 25 -fold change (from 2.54 to $0.1 \mathrm{mM}$ ) in the external concentration of $\mathrm{Ca}$ in the isolated rat pancreas. Williams and Chandler (21) showed that the dose-response relation for bethanechol stimulation of pancreatic amylase release in a Ca-deficient medium was shifted downward by about $50 \%$, but was strikingly parallel to the relation obtained in $2.56 \mathrm{mM} \mathrm{Ca}$. The relations, however, were obtained in doses of bethanechol over the range $3 \times 10^{-7} \mathrm{M}-10^{-5} \mathrm{M}$. Renckens, Schrijen, Swarts, de Pont and Bonting (19) showed that $10^{-5} \mathrm{M}$ carbachol induced pancreatic protein release from isolated rabbit pancreas even in a $\mathrm{Ca}$-free medium.

The investigation was supported by grants to one of the authors (T. K.) from the Ministry of Education, Science and Culture, Japan, and from the Mitsubishi Foundation.

Received for publication 22 December 1979

\section{REFERENCES}

1. Bernfeld P. (1955) Amylase $\alpha$ and $\beta$. In Methods in Enzymology' Vol. 1 (ed. Colow ICK S. P. and Kaplan N. O.), Academic Press, New York, pp. 149-158

2. CASE R. M. (1978) Synthesis, intracellular trans. port and discharge of exportable proteins in the pancreatic acinar cell and other cells. Biol. Rev. 53, 211-354

3. Case R. M. and Clausen T. (1973) The relationship between calcium exchange and enzyme secretion in the isolated rat pancreas. $J, P h y$ siol. 235, 75-102

4. Chance B., Cohen P., Jobsis F. and Schoener B. (1962) Intracellular oxidation-reduction states in vivo. Science 137, 499-508

5. Chandler D. E. (1978) Control of pancreatic enzyme secretion: a critique on the role of calcium. Life Sciences 23, 323-334

6. IsHIKAWA K. and KANNO T. (1978) Influences of extracellular calcium and potassium concen. trations on adrenaline release and membrane potential in the perfused adrenal medulla of the rat. Jap. J. Physiol. 28, 275-289

7. IVY A. C. and JANECEK H. M. (1959) Assay of Jorpes-Mutt secretin and cholecystokinin. Acta physiol. scand. 45, 220-230

8. Kanno T. (1972) Calcium-dependent amylase release and electrophysiological measurements in cells of the pancreas. J. Physiol. 226, 353-371

9. KanNo T. (1975) The electrogenic sodium pump in the hyperpolarizing and secretory effects of pancreozymin in the pancreatic acinar cell. J. Physiol. 245, 599-616

10. Kanno T. and Nishimura O. (1976) Stimulussecretion coupling in pancreatic acinar cells: in- 
hibitory effects of calcium removal and manganese addition on pancreozymin-induced amylase release. J. Physiol. 275, 309-324

11. Kanno T. and Saito A. (1978) Influence of external potassium concentration on secretory responses to cholecystokinin-pancreozymin and ionophore A23187 in the pancreatic acinar cell. J. Physiol. 278, 251-263

12. Kanno T., Saito A. and Sato Y. (1977) Stimulus-secretion coupling in pancreatic acinar cells: influences of external sodium and calcium on responses to cholecystokinin-pancreozymin and ionophore A23187. J. Physiol. 270, 9-28

13. Kanno T., Suga T. and Yamamoto M. (1976) Effects of oxygen supply on electrical and secretory responses of humorally stimulated acinar cells in the isolated rat pancreas. Jap. J. Physiol. 26, 101-115

14. Kanno T. and Yamamoto M. (1977) Differentiation between the calcium-dependent effects of cholecystokinin-pancreozymin and the bicarbonate-dependent effects of secretin in exocrine secretion of the rat pancreas. J. Physiol. 264, 787-799

15. Kobayashi S. (1974) Methods for direct read out of metabolic control in vitro. Seibutsu-
Butsuri 14, 226-237 (in Japanese)

16. Lehninger A. L. (1970) Mitochondria and calcium ion transport. Biochem. J. 119, 129-138

17. Lehninger A. L., Vercesi A. and Bababunmi E. A. (1978) Regulation of $\mathrm{Ca}^{2+}$ release from mitochondrial by the oxidation-reduction state of pyridine nucleotides. Proc. Natl. Acad. Sci. US A 75, 1690-1694

18. Petersen O. H. and Matthews E. K. (1972) The effect of pancreozymin and acetylcholine on the membrane potential of the pancreatic acinar cells. Experientia 28, 1037-1038

19. Renckens B. A. M., Schrijen J. J., Swarts H. G. P., De Pont J. J. H. H. M. and Bonting S. L. (1978) Role of calcium in exocrine pan. creatic secretion. IV calcium movements in isolated acinar cells of rabbit pancreas. Biochim. Biophys. Acta 544, 338-350

20. Saito A. and Kanno T. (1973) Concentration of pancreozymin as a determinant of the exocrine-endocrine partition of pancreatic enzymes. Jap. J. Physiol. 23, 477-495

21. Williams J. A. and Chandler D. (1975) $\mathrm{Ca}^{++}$ and pancreatic amylase release. Am. J. Physiol. 228, $1729-1732$ 